\title{
Tourism and air transport - an economic evaluation of the Oporto Airport expansion project
}

\author{
Turismo e transporte aéreo - a avaliação económica do projecto de ampliação do Aeroporto do Porto
}

\author{
Vânia Natércia Gonçalves Costa \\ School of Hospitality and Tourism, Polytechnic Institute of Cávado and Ave; \\ CiTUR; GOVCOPP and UNIAG; Campus do IPCA, Vila Frescaínha S. Martinho, 4750-810 Barcelos, Portugal, \\ vcosta@ipca.pt
}

\begin{abstract}
Over the past few years the rate of air transport use has increased, making it a crucial sector of activity in economic and tourism development. It has become essential to adapt airport infrastructures to the new requirements of demand. This study aims evaluate and quantify, in socio-economic terms, the impact of investment of an airport infrastructure expansion project. This research focused on a case study of the Oporto Airport, the investment in expanding the capacity of the entire airport infrastructure from three to 11 million passengers the expansion project of this airport, which ran from 2000 to 2007 and involved a total investment of $€ 407$ million. The methodology used is based on the economic evaluation, concretely applying the cost-benefit analysis method, which compares the social benefits and decision costs. According to the results obtained, the expansion project of Oporto Airport is expected to be a good investment from a socioeconomic viewpoint.
\end{abstract}

Keywords: Airport, cost-benefit analysis, economic evaluation, infrastructures, tourism.

\section{Resumo}

Nos últimos anos a taxa de utilização do transporte aéreo aumentou, tornando-se um setor de atividade crucial para o desenvolvimento económico e turístico. Tornou-se essencial adaptar as infraestruturas aeroportuárias às novas exigências da procura. Este estudo visa avaliar e quantificar, em termos socioeconómicos, o impacto do investimento do projeto de ampliação da infraestrutura aeroportuária. Este estudo centrou-se num estudo de caso do Aeroporto do Porto, concretamente no investimento de ampliação da capacidade de toda a infraestrutura aeroportuária de três para 11 milhões de passageiros, que decorreu entre 2000 e 2007 e envolveu um investimento total de 407 milhões de euros. A metodologia utilizada baseia-se numa avaliação económica, concretamente aplicando o método de análise de custo-benefício, que compara os benefícios sociais e os custos da decisão. De acordo com os resultados obtidos, o projecto de ampliação do Aeroporto do Porto prevê-se como bom investimento do ponto de vista socioeconómico.

Palavras-chave: Aeroporto, análise custo-benefício, avaliação económica, infraestruturas, turismo.

\section{Introduction}

Tourism is a strategic sector for the development of economies, particularly those that possess tourism resources of interest. Tourism and travel is an important economic activity in most countries around the world, the sector generates nearly $10 \%$ of economic output and 313 million jobs, supports 1 in 10 jobs in the global economy or 9.9\% of total employment in 2017 (UNWTO, 2018). The air transport subsector is one of the most strategic of all sectors of activity, from both the government and business standpoints, since it solves issues in the mobility of people and goods, acting as an economic leverage of other activities. Aviation is a means of transport of growing importance in tourism markets (Graham, Papatheodorou \& Forsyth, 2008). Air transport is the main means of transportation worldwide, is a primary mode of transport for international leisure travel and an important influence on destination development (UNWTO, 2015). In 2017 , around $57 \%$ of all tourists travel to their destination by air, $37 \%$ by road transport, $4 \%$ by water and just $2 \%$ in a rail transport (ATAG, 2018).

In 1987, the intense growth of the air sector, excessive regulation, the market crash and low levels of competitiveness stimulated a process of liberalisation of European air space, which then continued for 10 years. Consequently, over the past 15 years, air transport has radically changed in Europe. Since the conclusion of the liberalisation process in 1997, the growth of low cost companies, arising from aggressive policies and prices, completely changed what is on offer and boosted demand. Currently, strong price competition has stimulated the demand for medium distance trips for those wishing to enjoy short holidays or weekends in cities attractive to tourists. The growth of these companies, together with the emergence of websites aggregating offers (flights, hotels and other tourism services), has resulted in a wider range of choice for tourists, at the same time, reducing the power of travel agencies and tourism operators in general. These changes have favoured the growth of tourism destinations and less conventional cities. The increase of visitors to these destinations results from the combination of an attractive tourism offer, availability of services in quantity, quality and variety, as well as good integration between airline carriers, local airports and regional and local authorities.

The air transport subsector is one of the most strategic of all sectors of activity, from both the government and business standpoints, since it solves issues in the mobility of people and goods, acting as an economic leverage of other activities. Thus, it has become essential to adapt airports and their infrastructure to the new requirements of supply and demand. The study discussed here carried out a cost-benefit analysis of Oporto Airport's infrastructure, focusing on the assessment of 
investment to promote an expansion of the airport's installed capacity. This project of Oporto Airport came out of the Francisco Sá Carneiro Airport 2000 Master Plan (ANA, 2000). This study aims at evaluating the social return on this investment in expanding the capacity of the entire airport infrastructure from three to 11 million passengers. In its methodology, this study uses as its basis the manual for economic evaluation by Rus et al. (2010) and the study by Jorge and Rus (2004). In particular, to examine how the behaviour of Oporto Airport passengers affects the capacity problems of the airport infrastructure, we use the traffic data available and use forecast data available in studies on Oporto Airport.

In order to meet the proposed objectives, this article is divided into five parts. After the introduction, the second part outlines the. literature review and the third part describes the methodology used. Section four presents a case study evaluating the project to expand Oporto Airport, which ran from 2000 to 2007 and involved a total investment of $€ 407$ million. We start by analysing the investment and subsequently quantifying the variations arising from it, namely, the change in producer surplus (airport services and airlines), the change in consumer surplus (existing traffic and the traffic generated) and the change in surplus for the rest of society. Finally, we present the results of the project evaluation.

\section{Literature review}

The increased connectivity produced by air transport has significant effects on the growth of regional economies, as it creates jobs, stimulates economic activity, attracts foreign investment and increases the entry of tourists. European Commission recognises the importance of transportation and considers it to be a basic infrastructure in the European economy and society (Zuidberg \& Veldhuis, 2012). Thus, according to the authors, airports play an important role in the access to different of European regions and the rest of the world, and, in particular, regions with lower gross domestic product benefit from an increase in receptive tourism.

The adaptation of these infrastructures and their entire evolution has been extremely significant from diverse points of view. This implies investments that involve, in many cases, considerable monetary values. The analysis and, crucially, the quantification of the impact of this investment are of relevance, requiring the use of various methods of project analysis, depending on the context of each study. From the economic point of view, in the private sector, project evaluation involves a monetary evaluation, in which the respective project approval requires companies to maintain a positive balance between revenues and expected costs. From the social point of view, as Dalbem, Brandão and Macedo-Soares (2010) state, future benefits of the project include revenues and costs analysed from a private sector stand point and global factors directly related to social welfare. These can be the economic development of industries and regions and improvement in quality of life, among others. Thus, according to the authors, the feasibility of projects can be considered of interest to society, regardless of financial returns created for private investors.

According to Lizana, Reyes and Moreno (1996), the economic impacts of airports, that is, the economic repercussions around their activities, arise from the moment their construction starts. Therefore, before proceeding with airport projects, it is crucial that these same impacts be quantified and the overall study be carried through into a prospective follow-up and reflection. Airports generate many jobs, and the quality of airports' offer influences the location of value-added activities, since airports are the entry point for many non-resident tourists. As a result, demand growth and market expansion have generated the need for adaptation on the part of airport infrastructures (Bel \& Fageda, 2007).

According to Dalbem, Brandão and Macedo-Soares (2010), Samuelson was the first progenitor of the foundations of economic analysis. Based on this economist's work, the first evaluation methodologies emerged in the last century and were developed in European countries and the United States. Specifically, in the 1960's, studies such as Arrow's (1963) and Beesley's (1965) emerged in the literature. These kinds of studies appeared most prominently in the eighties, with a special emphasis on England and Holland. Over time, various studies have sought to improve methodologies for measuring and quantifying economic benefits and all associated impacts tangible and intangible - making the whole assessment process more objective, according to Dalbem, Brandão and MacedoSoares (2010). Jorge and Rus (2004) presented a methodological approach for evaluating investment in infrastructure projects that involve the expansion of airport capacity, a method referred to as cost-benefit analysis. This analysis aims at evaluating the projects under time-restricted conditions and separating economically viable from unviable projects. The economic evaluation of transportation design, according to Rus et al. (2010), has the purpose of identifying and quantifying a project's relative effects on social welfare, considering aspects such as accidents and benefits in reducing transportation time.

Some studies have applied cost-benefit analysis to air transport, in particular the 2003 European Commission study (Advisory Council for Aeronautics Research in Europe, 2003) and the 2004 International Civil Aviation Organisation study (ICAO). This last had the objective of evaluating the impact of civil aviation throughout the world from 1998 data (ICAO, 2004). Other studies have been done by Graham and Dennis (2010) and Jorge and Rus (2004). In addition, to estimate the regional economic impact of Malaga Airport, Lizana, Reyes and Moreno (1996) used a methodology based on the recommendations of Airports Council International ( $\mathrm{ACl}$ ) Europe, as detailed in previous studies on several European and American airports (ACI Europe, 1986).

Diverse countries with great influence on the economic evaluation of projects, as well as some world organisations such as the World Bank, have moved towards structuring the evaluation process into common practices and methodologies. 
As a result, some manuals exist that aid the economic analysis of social impacts, including the documents Handbook of the World Bank (1996) and, specifically in the area of transport, Transport Notes of the World Bank. More recently, some manuals have been published on project economic evaluation, arising from investigations in several countries.

In Portugal, these methodologies have been applied to some infrastructure projects, although with some limitations. There is still room to develop in this area of expertise, to better establish this as a standard practice within public investment projects.

\section{Methodology}

In the literature, a transport project is considered an intervention on a market of transport that alters the balance that had previously been obtained in the same market and in the wider economy if such an intervention had not been conducted' (Rus et al., 2010). In this sense, the project evaluation results from its economic rationality, that is, a cost and benefit analysis of the whole life of the project and, thereafter, a calculation of its net benefit. A comparison between the existing balance in a scenario without a project and a scenario with a project must underlie the analysis of benefit.

In regional development, according to Lizana, Reyes and Moreno (1996), only the impact of this subsector's long-term growth are considered relevant, whereas the temporary economic impact of the airport construction are considered a side impact. This impact can be divided into two types: first, the impact on economic activities within the airport's operations, namely, direct, indirect and induced quantitative categories; and second, the qualitative impact on new and traditional unrelated economic activities. Therefore, it is important to distinguish three categories of quantitative economic impact:

i. Direct impact: originating from inside the airport as a result of the economic activities of the companies and actual management of the airport, such as the creation of employment in air transport's business sector;

ii. Indirect impact: arising from activities outside the airport's grounds, but which depend on its activities;

iii. Induced impact: on the regional economy, arising from the multiplier effect of direct and indirect impact, that is, impact that can be induced from the direct and indirect impact, such as the creation of employment in activities immediately adjacent to the air transport chain of production.

A comparison between the existing balance in a scenario without a project and a scenario with a project must underlie the analysis of benefit. Let us consider the example of transport between two situations within the study (Rus et al. 2010a), which is illustrated in Figure 1. Point A represents the initial equilibrium situation without the project and Point $B$ represents the balance after the project, in which an increase in supply occurs. An analysis of the economic benefits consists of the comparison between these two balances. However, it is important, in addition to assessing the present time $t$, to evaluate the future in $t+1$. As it can be observed, there are also two future balances, Point $C$ without the project and Point $D$ with the project.

\section{Figure 1 - Evaluation as a comparison of balances}

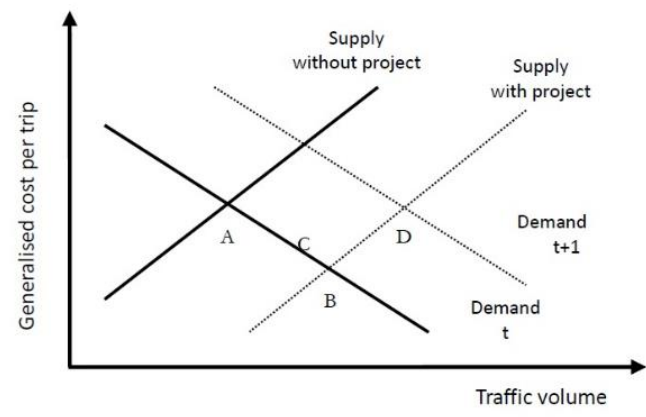

Source: Rus et al. (2010a).

In a project that expands airport capacity, Jorge and Rus (2004) argue that, in the initial situation, the scenario without the project includes a minimum investment to maintain the existing level of operational capability. The authors emphasise that the benefits of these investment projects fall into four categories:

i. Reduction in travel, access and waiting time;

ii. Improved services;

iii. Reduction in operating costs;

iv. Increased traffic.

These economic benefits directly affect airlines, taxpayers, airport services and airspace users. In addition, other economic agents can benefit, directly and indirectly, from the effects of substitution and complementarity. The importance of these effects in an economic evaluation depends on their magnitude. Dalbem, Brandão and Macedo-Soares (2010) stress that the details of who wins and who loses is critical to identify whether or not a project will achieve its objectives and, hence, is key information in an economic analysis. To calculate the net benefits of the project, the authors propose an analysis of the net benefits as shown in Figure 2. In this calculation, the consumer surplus is equal to the sum of Area $1\left(C_{0}, C_{1}, D, F\right)$ and Area $2(D, F, E)$ and the net social benefit is equal to Area 2 , since a project design can generate a generalised reduction of consumer costs. This is translated, in Figure 2 , into the decreasing cost of $C_{0}$ to $C_{1}$, resulting in an increase of traffic to $T_{1}$.

Figure 2 - Evaluation of the benefit of the project

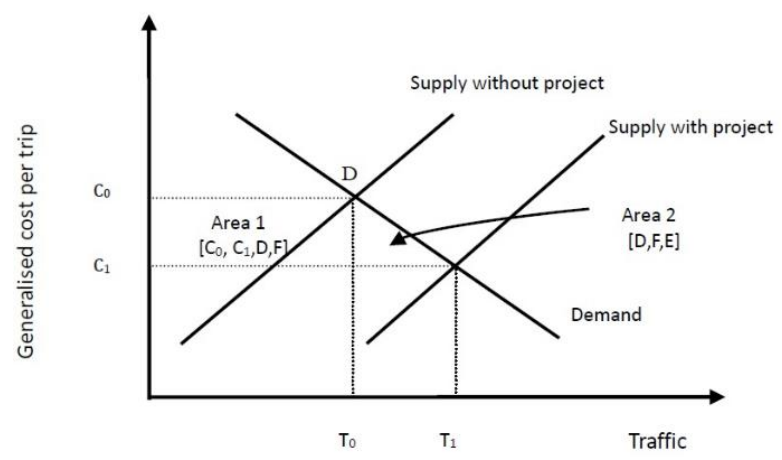

Source: Dalbem, Brandão and Macedo-Soares (2010). 
Consequently, according to Jorge and Rus (2004), the economic benefits of investment in airport infrastructure does not directly correspond to the revenues obtained by the airport authority and other commercial enterprises operating in the airport. The benefits of infrastructure investment on the 'landside' result from benefits that derive from preventing diversion of traffic to alternative modes of travel, imposing additional generalised transport costs and lowering congestion in passenger and freight terminals. This reduces the time of travel and thus decreases the general cost of travel. The establishment of boarding bridges increases the comfort of access to aircraft and, therefore, the quality of the trip. On the other hand, investments on the 'airside' increase the frequency of departure and variety of available routes in the airport, which reduces delays and accelerates the processing of aircraft operations, and, in turn, reduces the airlines' operating costs. The authors summarise the benefits of investment in 'airside' buildings and runway infrastructures, as well as support and access equipment, termed the 'landside'. This can be summarised by four categories, namely:

i. Reduced travel times in access and waiting time;

ii. Improvements in service reliability and predictability;

iii. Reduced operating costs;

iv. Increased traffic.

Thus, the net effect is a reduction in the generalised cost of travelling. According to Jorge and Rus (2004), the economic rationale of airport projects requires the identification and measurement of costs and benefits over the life of the project. It also necessarily includes a calculation of net present value and net benefit of the project, which is called the net present value (NPV) of the project, reflected by the following expression:

$$
N P V=-I+\sum_{t=1}^{T}\left(\Delta C S_{t}+\Delta P S_{t}(1+i)^{-t}\right.
$$

where $I$ is investment, $t$ is project time, $\Delta C S_{t}$ change in consumer surplus in year $t, \Delta P S_{t}$ change of supply excess in the year $t$ and $i$ the discount rate. According to the cited authors, changes in consumer surplus can be estimated with the following function:

$$
\Delta C S_{t}=\frac{1}{2}\left(g t_{0}-g t_{1}\right)\left(q t_{0}-q t_{1}\right)
$$

where:

$g_{t}=p_{t}-\tau_{t}$

$g t_{0}$ - generalised cost without investment in year $t$

$g t_{1}-$ generalised cost with investment in the year $t$

$q t_{0}$-airport users in the year $t$ without investment

$q t_{1}$ - airport users in the year $t$ with investment

$p t$ - price per trip including airport taxes, plane ticket and access costs

$\tau_{t}-$ value of the total travel time (flight, access, exit and standby)

Changes in excess supply can be translated by the following expression:

$$
\Delta P S_{t}=p t_{1}-q t_{1+} C_{t 0}\left(q t_{0}\right)-C_{t 1}\left(q t_{1}\right)
$$

where: $C_{t 0}\left(q t_{0}\right)$ and $C_{t 1}\left(q t_{1}\right)$ represent, respectively, the total variable costs without the project and with the project.

The analysis of cost and benefit implies estimating the airport demand for the entire lifetime of the project. Assuming a base level of initial demand value equal to $q_{0}$, the remaining quantities demanded would be calculated by applying the growth rate ${ }^{v}$. The present study was performed a posteriori, which permits the identification of the real demand for some of the years in the project's life.

\section{Evaluation of investment in the Oporto Airport expansion project}

Oporto Airport is the international airport for the northern region of Portugal. In recent decades, the airport recorded a growth in passengers, which is still increasing, although irregularly (see Table 1). From 2000 to 2017, it recorded an average annual growth rate of $9.5 \%$ and experienced a cumulative growth of $408 \%$. Oporto Airport's traffic, compared with the evolution of EU air traffic and total traffic in Portugal, has a much higher level of growth. Specifically, over the past 17 years, passenger traffic in the EU has grown by $58 \%$. In all Portuguese airports, it grew $68 \%$, but Oporto Airport showed a cumulative traffic increase of approximately $408 \%$.

Table 1 - Evolution of passengers for Oporto Airport from 2000 to 2017 (in thousands)

\begin{tabular}{|l|c|c|c|c|c|c|c|c|c|c|c|c|c|c|}
\hline & 2000 & 2005 & 2006 & 2007 & 2008 & 2009 & 2010 & 2011 & 2012 & 2013 & 2014 & 2015 & 2016 & 2017 \\
\hline Total & 2,123 & 3,110 & 3,405 & 3,988 & 4,536 & 4,509 & $\mathbf{5 , 2 8 2}$ & $\mathbf{6 , 0 0 5}$ & $\mathbf{6 , 0 5 1}$ & $\mathbf{6 , 3 7 2}$ & $\mathbf{6 , 9 3 2}$ & $\mathbf{8 , 0 8 9}$ & $\mathbf{9 , 3 7 8}$ & $\mathbf{1 0 , 7 8 9}$ \\
\hline$\Delta \%$ & $25.0 \%$ & $5.6 \%$ & $9.5 \%$ & $17.2 \%$ & $13.7 \%$ & $-0.6 \%$ & $17.1 \%$ & $13.7 \%$ & $0.8 \%$ & $5,31 \%$ & $8,79 \%$ & $16,70 \%$ & $15,94 \%$ & $15,05 \%$ \\
\hline
\end{tabular}

In order to cope with this evolution in demand, the need emerged for increased supply. As a result, the strategic growth plan for the airport incorporated a project to create an increased installed capacity in the airport's infrastructure. This was named the Oporto Airport 2000 Master Plan. According to Tribunal de Contas (2009), this master plan emerged from a need to upgrade the maximum capacity of the airport to 15 million passengers per year, given the surrounding land area available and the potential for capturing demand in three major surrounding areas. Thus, the airport has features that allow links between major European regular connections, designated 'European hubs'. The investment has affected almost the entire airport infrastructure and led to the widening of the terminal, the construction of a new control tower, an increased number of aircraft parking positions, the building of new infrastructure and technical facilities and an increased operability of tracks, resulting in an increased capacity for aircraft movements (Tribunal de Contas, 2009). The master plan of the project laid out a strategy for the medium and long term, in three phases. The first phase (up to 2010) meant an estimated increase in 
capacity to six million passengers, 30 aircraft per hour, and a cargo complex with an annual processing capacity of 40 tonnes. In the second phase (2025) and the third phase, the strategic objective is to increase the capacity of the airport infrastructure to 11 and 15 million passengers annually, respectively.

However, the investment made from 2000 to 2007 resulted in an increased airport capacity equivalent to the one provided in the master plan for the second phase. The airport reached, as mentioned above, an installed capacity of 11 million passengers. In this way, the airport's traffic increased from an average of 2.8 million passengers in 1999, which was clearly attained despite some restrictions and bottlenecks, especially at check-in, baggage storage and processing on platforms. The strategic development plan for Oporto Airport provided for a growing and phased intervention over an extended period of time. Specifically, within this expansion, the airport invested in prolonging the taxiway (TWYA) and expanding the air cargo logistics centre (CLCA), as well as areas of real estate development and transferring service (TBP). Next, the intervention plans to relocate the track, convert the current TWYA runway, continue expanding the CLCA, increase the TBP and relocate the fuel farm and radar. In the final phase, the investment intends to expand the passenger terminal, increase technical areas and relocate the air traffic control tower (TWR).

In order to assess the appropriateness of the Oporto Airport expansion, we did a cost-benefit analysis of the investment project. We considered the investment period of the first expansion phase of Oporto Airport, specifically 2000 to 2007, with 2000 as the assessment base year, and thus the year off. The investment was valued in euros for 2000 , and a discount rate of $6 \%$ was considered, in order to update all values to 2000 , according to the general criteria recommended by the European Commission for cohesion countries (European Commission, 2008). In this analysis, we assessed the social impact of this investment, taking as the central element the increase in demand induced by LCC in recent years. The investment in the first phase of the Oporto Airport expansion amounted to $€ 406,937,797$, a figure including value added tax (VAT), which was subdivided into $92 \%$ of the investment for labour costs, $6 \%$ for preparatory labour and $1 \%$ for amounts paid as compensation for expropriation (see Table 2). The entire amount was financed by equity capital $(42.8 \%)$, debt capital from structural funds (6.1\%) and banks (51.1\%). In our analysis, we used the value of the investment without VAT. Accordingly, the total investment was around $€ 313,342,103.69$. The general findings of the evaluation of this project are outlined in Table 3.

Table 2 - Global cost of labour

\begin{tabular}{|c|c|c|c|c|c|c|}
\hline \multirow{2}{*}{$\begin{array}{l}\text { Categories } \\
\text { of investment }\end{array}$} & & \multicolumn{4}{|c|}{ Sources of funding } & \multirow[b]{2}{*}{$\%$} \\
\hline & Total with VAT & ANA, SA & $\begin{array}{c}\text { European } \\
\text { Investment Bank }\end{array}$ & $\begin{array}{l}\text { European Regional } \\
\text { Development Fund }\end{array}$ & $\begin{array}{c}\text { Other } \\
\text { bank loans }\end{array}$ & \\
\hline Construction labour & $375,044,920$ & $142,114,835$ & $168,000,000$ & $24,930,085$ & $40,000,000$ & $92 \%$ \\
\hline Preparatory labour & $26,300,984$ & $26,300,984$ & & & & $6 \%$ \\
\hline Expropriation & $5,591,893$ & $5,591,893$ & & & & $1 \%$ \\
\hline Total costs of the work & $406,937,797$ & $174,007,712$ & $168,000,000$ & $24,930,085$ & $40,000,000$ & $100 \%$ \\
\hline
\end{tabular}

Table 3 - General information for the evaluation of the Oporto Airport expansion project

\begin{tabular}{|c|c|}
\hline Year Discount & 2000 \\
\hline Currency & $€-2000$ \\
\hline Duration of investment & 2000-2007 (March 2007) \\
\hline Evaluation period & $2000-2036$ \\
\hline Discount rate & $6 \%$ \\
\hline Time value & $\begin{array}{l}€ 12.43 / \text { hour - for the time value, we distinguish between leisure time and work time. According to data from the } \\
\text { European Commission (2006), in } 2002 \text {, the average savings for Portugal travel time for the segment of passengers } \\
\text { travelling for work purposes was } € 26.63 / \text { hour, and the mean value of the savings to Portugal travel time for the } \\
\text { segment of passengers travelling for leisure was } € 10.47 / \text { hour. Accordingly, considering that } 80 \% \text { of Oporto Airport } \\
\text { passengers travel for pleasure and the remaining } 20 \% \text { travel for work, the average time was of } € 13.70 / \text { hour. } \\
\text { Adjusting the reference value of } 2002 \text { to } 2000 \text {, this value was about } € 12.43 / \text { hour. }\end{array}$ \\
\hline $\begin{array}{l}\text { Forecast scenario } \\
\text { without project }\end{array}$ & $\begin{array}{l}\text { To the actual volume of passenger traffic, up to } 2006 \text { and from } 2007 \text { onwards (the completion time for the } \\
\text { investment project), an average annual passenger growth of } 3.58 \% \text { was applied, which is equivalent to the average } \\
\text { annual rate of growth from } 2000 \text { to } 2006 \text {. }\end{array}$ \\
\hline $\begin{array}{l}\text { Forecast scenario with } \\
\text { project }\end{array}$ & $\begin{array}{l}\text { Real traffic known to the completion date of this study, for } 2012 \text { and forecast of three scenarios for 2013-2036: } \\
\text { 1) Scenario 1: average annual growth of 5.6\%, from Proença, Afonso, Gil and Alves (2012); } \\
\text { 2) Scenario 2: average annual growth of } 6.5 \% \text {, from Proença, Afonso, Gil and Alves (2012); } \\
\text { 3) Scenario 3: lower average growth rate in proportion to Scenario } 1 \text { and Scenario } 2 \text { rates, lower by } 0.9 \\
\text { percentage points, or } 4.7 \% \text {. }\end{array}$ \\
\hline Capacity constraint & Capacity limit of 11 million passengers \\
\hline
\end{tabular}


According to the evaluation manual in the study by Rus et al. (2010), the change in producer surplus translates into the following expression:

$$
\Delta E P=\left(p_{t}^{1} q_{t}^{1}-p_{t}^{0} q_{t}^{0}\right)-\left(C_{t}^{1}-C_{t}^{0}\right)
$$

where:

$\mathrm{p}_{\mathrm{t}}^{1}$ - prices with project; $p_{t}^{0}$ - prices without project; $q_{t}^{1}$ - traffic project with capacity constraint; $q_{t}^{0}$ - existing traffic without project and with capacity constraint; $C_{t}^{1}-$ costs with project; $C_{t}^{0}$ - costs without project.

To determine the costs of Oporto Airport, since ANA's statement of accounts only provides consolidated accounts for all airports in Portugal, we cannot separately analyse the operating costs of the airport. Because of this, to determine costs, we analysed some statistical data from Oporto Airport and some sources that we will cite below. According to the study by Cegea and Trenmo (2007), fixed costs of airports are associated with investments in airport infrastructures, such as terminals, runways and other equipment. On the other hand, variable costs include mainly personnel costs and the cost of supplies and services from outside airports. The abovementioned authors analysed the cost structure of airport activity, creating a database of 58 airports from Europe, the United States, Asia and the Pacific from the information published by the Air Transport Research Society (ATRS, 2007). To permit the comparison of data, the authors corrected the values using the exchange parity of purchasing power for the respective countries.

From the analysis of variable costs, Cegea and Trenmo's (2007) study supported the conclusion that the United States has lower operating costs than the Europeans do, which, according to the authors, stems from the lower level of service provided by the airports themselves. Regarding LCC airports, the authors did not find lower costs, which may result from a greater number of services offered by the airports.

In the case of Portuguese airports, the authors determined an operating cost per passenger of about $€ 7.96$, which is considered well below the European average (see Table 4).

Table 4 - Variable costs for airports in Europe, America, Asia and the Pacific and Portugal (2005 values)

\begin{tabular}{|c|c|c|c|c|c|c|}
\hline \multirow{2}{*}{ Regions } & \multirow{2}{*}{ Observations } & \multicolumn{3}{|c|}{ Operating costs per $10^{6}$ passengers } & \multirow{2}{*}{$\begin{array}{c}\text { Employment by } 10^{6} \\
\text { passengers }\end{array}$} & \multirow{2}{*}{$\begin{array}{l}\text { Soft input } \\
\text { cost }\end{array}$} \\
\hline & & USD & PPP & EUR & & \\
\hline EUA & 16 & 6.58 & 6.43 & 5.30 & 33.68 & 3.11 \\
\hline Europe & 33 & 14.51 & 13.85 & 11.68 & 116.48 & 1.48 \\
\hline Asia and the Pacific & 36 & 9.80 & 11.55 & 7.89 & 43.02 & 0.96 \\
\hline Low cost carriers & 4 & 10.52 & 8.94 & 8.47 & 47.74 & 0.60 \\
\hline Full-service & 54 & 11.67 & 11.64 & 9.40 & 84.79 & 1.65 \\
\hline International hub & 14 & 11.85 & 12.54 & 9.54 & 61.54 & 2.56 \\
\hline Other full-service & 39 & 11.61 & 11.29 & 9.34 & 93.74 & 1.30 \\
\hline Total & 58 & 11.59 & 11.45 & 9.33 & 82.24 & 1.94 \\
\hline ANA, Portugal & & 9.90 & 11.31 & 7.96 & 65.21 & n.d. \\
\hline
\end{tabular}

Source: Cegea and Trenmo (2007).

Since there are no reliable estimates for the fixed costs of various international airports, the authors analysed the variable costs. According to Rus et al. (2010), costs at Spanish airports are expressed by the following function:

$$
C T=c v_{1} * P a x
$$

where:

$\mathrm{CT}$ - total costs of the airport; Pax - number of passengers; $c v_{1}$ - unit variable costs.

Applying the average data in the study of Portuguese airports by Cegea and Trenmo (2007), for 2005, we obtained the following function:

$$
C T=7.96 \text { Pax }
$$

Correcting the values for parameters of inflation for 2000 to 2005:

$$
\mathrm{CT}=6.80 \mathrm{Pax}
$$

With regard to airport revenues, according to Cegea and Trenmo (2007), these do not depend solely on internally performed production, since they include production outsourced to third parties. Furthermore, airports grow on the basis of airport revenue and non-airport revenue, that is, total revenues include revenues from activities directly related to the use of airport infrastructures. These include revenues from flight operations, terminal operations and ground operations, and revenues that, while important to airports, are not directly related to air transport functions, such as income received for the rental of commercial spaces and derived from car parking. Analysing only the operational or airport revenues within the Portuguese airspace, according to the same study, each airport has, on average, a revenue of $€ 12.29$ per passenger.

$$
R T=12.29 \operatorname{Pax}
$$

where:

$R T$ - total 2005 revenues in $€$; Pax - number of passengers By fixing for inflation from 2000 to 2005 , the corrected formula arises:

$$
\mathrm{RT}=10.50 \mathrm{Pax}
$$

The change in producer surplus $(\triangle E P)$ is calculated as the difference between changes in costs and revenues, that is, the variation generated by the traffic resulting from the airport expansion project.

$$
\Delta \mathrm{EP}=\Delta \mathrm{RT}-\Delta \mathrm{CT}
$$


The change in consumer surplus results from the reduction in travel time. The expression of the calculation of that surplus is given by:

$$
\Delta E C \text { (existing traffic })=v_{t} *\left(t_{0}-t_{1}\right) * q_{b}
$$

where:

$\mathrm{v}_{\mathrm{t}}-$ time value; $t_{0}$ - time of travel without project and with capacity constraint; $t_{1}$ - time of travel with project and with capacity constraint; $q_{b}$ - passengers without project and with capacity constraint.

Regarding travel times with and without the project, given the lack of concrete information for Oporto Airport, we estimate an initial savings from the project of 25 minutes, which is expected to be maintained for the first four years. Subsequently, given the increased congestion, we anticipate that this reduction in travel time decreases $10 \%$ every five years as a result of increased traffic congestion, up to a maximum traffic capacity of $11,000,000$ passengers.

Thus, the consumer surplus traffic results in the following expression:

$\Delta \mathrm{EC}$ (induced traffic) $=\frac{1}{2} *\left(\mathrm{t}_{0}-\mathrm{t}_{1}\right) *\left(\mathrm{q}_{\mathrm{d}}-\mathrm{q}_{\mathrm{b}}\right) \quad$ [12]

To calculate the variation of the negative externalities, we calculated the environmental impact generated by induced air traffic for Oporto Airport, calculated the social cost associated with environmental cost and considered the total external cost of air transport. These effects are based on the cost in euros per capita, estimated by Delft and Infras (2011). Based on this, we assumed the cost of $€ 55$, estimated by the above-cited study for 2008 , for Portugal, and we adjusted the value for passengers in all Portuguese airports. Considering the total of 1,500,000 inhabitants in the isochronous area of 30 minutes from Oporto Airport, we determined an environmental cost, at 2000 prices, of approximately $€ 1.74$ per passenger.

$$
\operatorname{CAT}(\mathrm{OPO})=1.74 € * \mathrm{Pax}
$$

The variation of the total environmental cost results from applying this average rate with differential environmental passengers with design and capacity constraints and with passengers without the project and with capacity constraints.

In order to assess the social impact of the project, given certain restrictions on statistical information, we chose to calculate the passengers in the first year of the project, setting the NPV at zero. According to the data, we concluded that the project would have a zero NPV investment with 2,902,292 passengers in 2007, assuming Scenario One. Assuming Scenario Three, the zero NPV would be reached with a total traffic of 3,890,795 passengers. Finally, in Scenario Two, the project would have a null value with 2,421,981 passengers. A comparative analysis of known actual passengers carried from 2007 to 2012 and the forecasted passengers in the three scenarios under consideration supports the conclusion that the real traffic of $3,988,388$ passengers was higher than that estimated in the context of the NPV equal to zero. Thus, it is estimated that the evaluation results of the project are positive.

In order to obtain an estimate of the NPV, we considered the actual values of passengers from 2000 to 2012, and, as of this date, we have completed three analyses, one for each one of the future scenarios - Scenario One, Two and Three. In Scenario One, with a growth rate of 5.6\% for traffic, from 2013 to 2036, we concluded an NPV of $€ 71,035,012.37$, maintaining the capacity constraint at $6,000,000$ without the project and $11,000,000$ with the project. In Scenario Two, with a growth rate of $6.5 \%$ traffic, we found a slightly higher NPV of $€ 158,260,868.66$. Finally, assuming Scenario Three, with an average annual growth of $4.7 \%$, we calculated an NPV of $€ 36,333,188.03$.

Factoring in the probability of each scenario, namely $80 \%$ for Scenario One and 10\%, respectively, for Scenarios Two and Three, the weighted average of the estimated NPV is approximately $€ 76,287,416$. Therefore, we conclude that the investment project to expand Oporto Airport resulted in a positive impact, both from the point of view of social benefits to consumers and to the producer, that is, to the airport itself.

\section{Conclusion}

This study examined the expansion of Oporto Airport under the 2000 Master Plan, which called for an increase in the airport's installed capacity. We carried out a cost-benefit analysis of this investment project, which took shape from 2000 to 2007, involving a total cost of about $€ 321,480,859$ (excluding VAT). In the calculation of benefits, we considered the benefit to existing consumers and induced traffic, looking at the time savings resulting from the enhancement of capacity. We also considered the benefit to producers coming from the variation of results for induced traffic. Additionally, we considered, as a burden of the investment project, environmental costs resulting from increased traffic.

According to the results obtained, the expansion project of Oporto Airport is expected to be a good investment from a socioeconomic viewpoint. Regarding social increases and benefits, we found a positive change in consumer surplus, both for existing and induced traffic. However, it should be noted that these calculations are based on estimates of time savings transferred from other airport contexts with of similar capacity expansions.

The producer surplus, namely the airport surplus, also revealed positive tendencies. As expected from the outset, the increased traffic generated by the expansion project increased environmental costs. A comparison of the updated flow of cost and benefit associated with this airport expansion project produces a positive differential, which indicates that this investment in capacity is socioeconomically profitable. Specifically, the results reflect an NPV of $€ 71,035,012.37$, assuming Scenario One for traffic growth; of $€ 158,260,868.66$ in Scenario Two and €6,333,188.03 in Scenario Three. From these 
scenarios, considering an $80 \%$ probability of occurrence of Scenario One and $10 \%$ of both Scenarios Two and Three, we obtain a weighted average NPV of $€ 76,287,416$.

Given that traditional assessment based on a set of parameters and estimates is subject to high levels of uncertainty, a reverse evaluation was carried out. This aimed at identifying the traffic volumes that would allow the airport infrastructure to get a zero net present value, assuming three possible scenarios (1, 2 and 3). Thus, given that the benefits of a variable nature outweigh the costs of the same nature, traffic amounts above those obtained in the reverse evaluation would ensure a positive NPV for the project. This exercise supported the conclusion that the project would get a zero NPV if, in 2007, the airport had recorded a total of 2,902,292 passengers in Scenario One, 2,421,981 in Scenario Two and 3,890,795 in Scenario Three. The results obtained show, beyond any doubt, positive social welfare has resulted from investment in the project to expand Oporto Airport.

\section{References}

Advisory Council for Aeronautics Research in Europe (2003). The Economic Impact of Air Transport on the European Economy.

ACI Europe (1986). Economic Impact Study Kit, Europe. Brussels: ACI Europe.

ANA Aeroportos de Portugal [ANA] (2000). Plano Diretor Aeroporto Francisco Sá Carneiro 2000. Lisboa: ANA Aeroportos de Portugal.

ANA Aeroportos de Portugal [ANA] (2001 to 2018). Relatório de Tráfego, Dezembro de 2001 to 2017 - Aeroporto do Porto. Lisboa: ANA Aeroportos de Portugal.

ANA Aeroportos de Portugal [ANA] (2007b). Plano Director Aeroporto Francisco Sá Carneiro 2007. Lisboa: ANA Aeroportos de Portugal.

ANA Aeroportos de Portugal [ANA] (2009a). Porto Airport. Lisboa: ANA Aeroportos de Portugal.

ANA Aeroportos de Portugal [ANA] (2009 and 2011b). Perfil do passageiro de 2009 e 2011. Lisboa: ANA Aeroportos de Portugal.

ANA Aeroportos de Portugal [ANA] (2013). Turismo e Internacionalização da Região Norte: Desafios \& Oportunidades. O caso do Aeroporto do Porto. Lisboa: ANA Aeroportos de Portugal.

Arrow, K. (1963). Uncertainty and welfare economics of medical care. American Economic Review, 53(5), 941-973.

ATAG (2018). Aviation benefits beyond borders. ATAG - Air Transport Action Group, October 2018.

ATRS (2007). Airport Benchmarking Report, Air Transport Research Society.

Beesley, M. (1965). The value of time spent in travelling: some new evidence. Economica, New Series, 32(126), 174-185.

Bel, G. and Fageda, X. (2007). Aeropuertos, movilidad y crecimiento económico. Anuario de la movilidad, Fundación RACC, 141-150.

Cegea and Trenmo (2007). Avaliação Económica do Mérito Relativo da Opção Portela + 1" - Estudo de impacte da localização de um novo aeroporto na região de Lisboa. Porto: Associação Comercial do Porto.

Dalbem, M., Brandão, L. and Macedo-Soares, T. (2010). Avaliação económica de projetos de transporte: melhores práticas e recomendações para o Brasil. Revista de Administração Pública, 44, 87-117.

Delft, C.E. and F.I. Infras (2011). External Costs of Transport in Europe, Update Study. Retrieved May, 8, 2013 from http://www.cedelft.eu/publicatie/external_costs_of_transport_in_eur ope/1258.

Dennis, N. (2002). Long-term route traffic forecasts and flight schedule pattern for a medium-sized European airport, Journal of Air Transport Management 8, 313-324.

European Commission (2006). HEATCO Deliverable 5. Proposal for Harmonised Guidelines. Unión Europea. DG Energía y Transportes.

European Commission (2008). Guide to Cost-benefit analysis of investment projects Structural Funds, Cohesion Fund and Instrument for Pre-Accession. Directorate General Regional Policy, The CBA Guide Team.

Graham, A. and Dennis, N. (2010). The impact of low cost airline operations to Malta, Journal of Air Transport Management, 16, 127-136.

Graham, A., Papatheodorou, A. \& Forsyth., P. (2008). Aviation and tourism: implications for leisure travel. Ashgate: UK.

ICAO (2004). Economic Contribution of Civil Aviation, Volume 1 , International Civil Aviation Organisation, Montreal, Canada. Report by Council on Evaluation of the Economic Contribution of Civil Aviation, Montreal, Canada.

Jorge, J. and Rus, G. (2004). Cost-benefit analysis of investments in airport infraestruture: a pratical approach, Journal of Air Transport Management, 10, 311-326.

Lizana, A., Reyes, M. and Moreno, O. (1996). El impacto de los aeropuertos sobre el desarrollo económico. Métodos de análises y aplicación al caso del aeropuerto de Málaga. Editorial Civitas-AENA.

Proença, J., Afonso, O., Gil, P. and Alves, R. (2012). Aeroporto Francisco Sá Carneiro, 2012-2020: Previsão de Movimento e Recomendação de Governance num Cenário de Privatização. Faculdade de Economia do Porto, Porto.

Rus, G., Betancor, O., Campos, J., Eugenio, J., Socorro, P., Matas, A., Raymond, J., Gonzálvez-Savignat, M., Brey, R., Nombela, G. and Benavides, J. (2010). Manual de evaluación económica de proyectos de transporte. Documento de trabajo. CEDEX. Ministério de Fomento. Retrieved December, 30, 2011 from www.evaluaciondeproyectos.es.

Tribunal de Contas (2009). Auditoria temática às derrapagens em obras públicas: Ampliação do Aeroporto Francisco Sá Carneiro. Relatório de auditoria no06/2009 AUDIT Processo 07/07, Lisboa.

UNWTO. (2015). UNWTO Tourism Highlights, 2015 edition. Madrid, Spain: World Tourism Organization.

UNWTO. (2018). UNWTO Tourism Highlights, 2018 edition. Madrid, Spain: World Tourism Organization.

World Bank. (1996). Handbook on Economic Analysis of Investment Operations. Washington: World Bank.

Zuidberg, J. and Veldhuis, J. (2012). The role of regional airports in a future transportation system. Amsterdam: SEO Economic Research.

Received: 15.03 .2019

Revisions required: 23.11 .2019

Accepted: 14.02 .2020 